\title{
Identification of two species of Binema Travassos 1925 (Oxyurida: Travassosinematidae) and Cameronia arecoensis Marchissio and Miralles 1987 (Oxyurida: Thelastomatidae) based on morphological and $18 \mathrm{~S}$ rRNA partial sequence
}

\author{
JOSÉ M. RUSCONI, MARTÍN MONTES, WALTER FERRARI and MARÍA FERNANDA ACHINELLY \\ Centro de Estudios Parasitológicos y de Vectores/CEPAVE (CCT La Plata, CONICET/ \\ UNLP), Calle 121 y 60 (1900) La Plata, Buenos Aires, Argentina \\ Manuscript received on August 13, 2018; accepted for publication on September 13, 2018
}

\begin{abstract}
How to cite: RUSCONI JM, MONTES M, FERRARI W AND ACHINELLY MF. 2019. Identification of two species of Binema Travassos 1925 (Oxyurida: Travassosinematidae) and Cameronia arecoensis Marchissio and Miralles 1987 (Oxyurida: Thelastomatidae) based on morphological and 18S rRNA partial sequence. An Acad Bras Cienc 91: e20180408. 10.1590/0001-3765201920180408
\end{abstract}

\begin{abstract}
Oxyurid nematodes parasitizing the mole cricket Neoscapteriscus vicinus were isolated in the framework of sampling fields of mole-crickets from the pampean region, in Argentina. In this work, molecular characterization of the 18S rRNA partial sequence of nematodes belonging to the families Thelastomatidae (Cameronia arecoensis Marchissio and Miralles 1987) and Travassosinematidae (Binema korsakowi Sergiev 1923 and Binema klossae, Marchissio and Miralles 1993) were carried out. This is the first world report of sequences belonging to $B$. klossae and $C$. arecoensis and first Argentinian report of $B$. korsakowi sequence. Also, morphological and morphometric features of B. klossae, B. korsakowi and $C$. arecoensis from Argentinian populations are reported.
\end{abstract}

Key words: Parasitism, mole-crickets, nematodes, gene markers.

\section{INTRODUCTION}

Thelastomatoidea is one of the superfamilies of the Oxyurida Order that mostly infects arthropods and is taxonomically separate from the vertebrate parasitizing Oxyuroidea superfamily (Basir 1956).

Adamson and van Waerebeke (1992a, b, c) recognize five families within this superfamily: Protrelloididae, found only in cockroaches; Hystrignathidae, exclusive of passalid beetles; Travassosinematidae, mainly cited in mole-crickets; Pseudonymidae, parasites of hydrophilic beetles and Thelastomatidae, with 31 genera parasitizing a great diversity of insects. These are exclusively

Correspondence to: María Fernanda Achinelly

E-mail: fachinelly@cepave.edu.ar

ORCid: http://orcid.org/0000-0003-2363-6661 intestinal parasites and their infective stages are the eggs which are ingested by the insect host (passive penetration), reaching the stomodeum where $\mathrm{J} 2$ hatch and the juveniles undergo successive molts reaching adulthood. Male dies after copulation and females reproduce by oviposition. Eggs are eliminated with faeces and wait to be ingested by a new host (Camino and Achinelly 2008).

In this work, oxyurid nematodes belonging to the families Thelastomatidae (Cameronia arecoensis Marchissio and Miralles 1987) and Travassosinematidae (Binema korsakowi Marchissioa and Miralles 1993 and Binema klossae Sergiev 1923) were isolated in the framework of sampling fields of mole-crickets from the pampean region, in Argentina. A morphological description and a 18S rRNA partial sequence characterization is also presented. 


\section{MATERIALS AND METHODS}

Nymphs and adults of the mole-cricket Neoscapteriscus vicinus found in Hudson $\left(34^{\circ}\right.$ 47' 25" S; 58 08' 55" W), Buenos Aires state, Argentina. The Pampean region is characterized by its warm climate and relatively high humidity, with an annual average temperature of approximately 14$15^{\circ} \mathrm{C}$ (Baldi et al. 2006). Insects were collected using a garden shovel and placed in individual recipients during spring and summer seasons of 2016.

The Poinar's (1975) technique was used to isolate the nematodes. Isolated insects were dissected in Petri dishes with distilled water under a stereomicroscope. Nematodes were isolated from the hind gut, killed in distilled water at $60^{\circ} \mathrm{C}$ for 2 minutes and then fixed in T.A.F. $(2 \%$ triethanolamine, $7.5 \%$ formaldehyde in distilled water). Specimens for molecular studies were fixed in absolute ethanol. Nematodes were measured using a camera lucida and an ocular micrometer in a Zeiss compound microscope. All measurements were given in micrometers unless otherwise stated. Photographs were taken with an Olympus DP-71 camera. Voucher specimens were deposited in the Museo de Ciencias Naturales de La Plata, Buenos Aires, Argentina.

To confirm the nematodes identification, a molecular approach was performed. Genomic DNA was extracted using $100 \mu 1$ of a $5 \%$ suspension of Chelex in deionized water and $2 \mu 1$ of proteinase $\mathrm{K}$, followed by overnight incubation at $56^{\circ} \mathrm{C}$, boiling at $90^{\circ} \mathrm{C}$ for 8 minutes and centrifugation at $14,000 \mathrm{rpm}$ for 10 minutes. An aliquot of 1 ul of the supernatant was utilized as template for PCR. The $18 \mathrm{~S}$ rRNA partial sequences were amplified using the primers Nem $18 \mathrm{SF}$ (5'-CGCGAATRGCTCATTACAACAGC-3') and Nem 18SR (5'-GGGCGGTATCTGATCGCC-3') according to Singh et al. (2013) with the Go Taq Master Mix (Promega). The thermocycler conditions were: $94^{\circ} \mathrm{C}$ for $15 \mathrm{~min} ; 35$ cycles of $94^{\circ} \mathrm{C}$ denaturation for $30 \mathrm{~s}$, annealing $52^{\circ} \mathrm{C}$ for $40 \mathrm{~s}$ and extension $72^{\circ} \mathrm{C}$ for $60 \mathrm{~s}$; a single final extension period of $72^{\circ} \mathrm{C}$ for $10 \mathrm{~min}$. PCR products were analyzed by electrophoresis on 1\% agarose gels and visualized by staining with ethidium bromide. The amplicons were sequenced in Macrogen Inc. (Korea), and edited with the platform GENEIOUS (http://www.geneious.com) (Kearse et al. 2012). The consensus sequences obtained were comparted with sequences in the BLAST tool available in the NCBI database (http://www.ncbi.nlm.nih. gov). The 18S rRNA partial sequence generated from this study were submitted to the National Center for Biotechnology Information (NCBI) GenBank database (http:// www.ncbi.nlm.nih.gov) and can be accessed using the GenBank accession numbers: MH055748, MH151853, MH151854 for B. korsakowi, B. klossae and C. arecoensis, respectively.

\section{RESULTS}

Family Travassosinematidae

Binema korsakowi (Sergiev 1923)

\section{DESCRIPTION}

Morphology

Female: body spindle shaped with its maximum width at the center, narrowing towards the extremities (Fig. 1a). Cuticule with few striations near the cephalic extremity. Oral opening with eight labiopapillae. Amphids with circular openings. A very short buccal cavity, almost absent. Oesophagus $366.3 \mu$ long, with a corpus, a short isthmus and a posterior valvular bulb. Nerve ring situated in the middle of the corpus. Excretory pore posterior to the basal bulb (Fig. 1b). Intestine dilated anteriorly, but this enlargement remains less in diameter than the oesophageal bulb. Vulva near the middle of the body, slightly posterior; vagina directed anteriorly (Fig. 1c). Two ovaries, one lying 
anteriorly and the other posteriorly, both reflexed. Each set of reproductive organs forming four loops; uteri divergent. Tail with conical form (Fig. 1d). Eggs bearing a bunch of filaments at each pole, laid in capsules, each capsule usually containing two or three eggs (Fig. 1e, 1f). The size of the capsule depends on the number of eggs contained in it. Individual eggs measure $36 \mu$ to $54 \mu$ long by $36 \mu$ to $45 \mu$ wide.

\section{Morphometry}

Female ( $\mathrm{n}=7)$ : total length: $2815.2(2112-3024)$, cephalic diameter: 21 (18-36), distance from anterior end to the nerve ring: 162.9 (99-207), width at
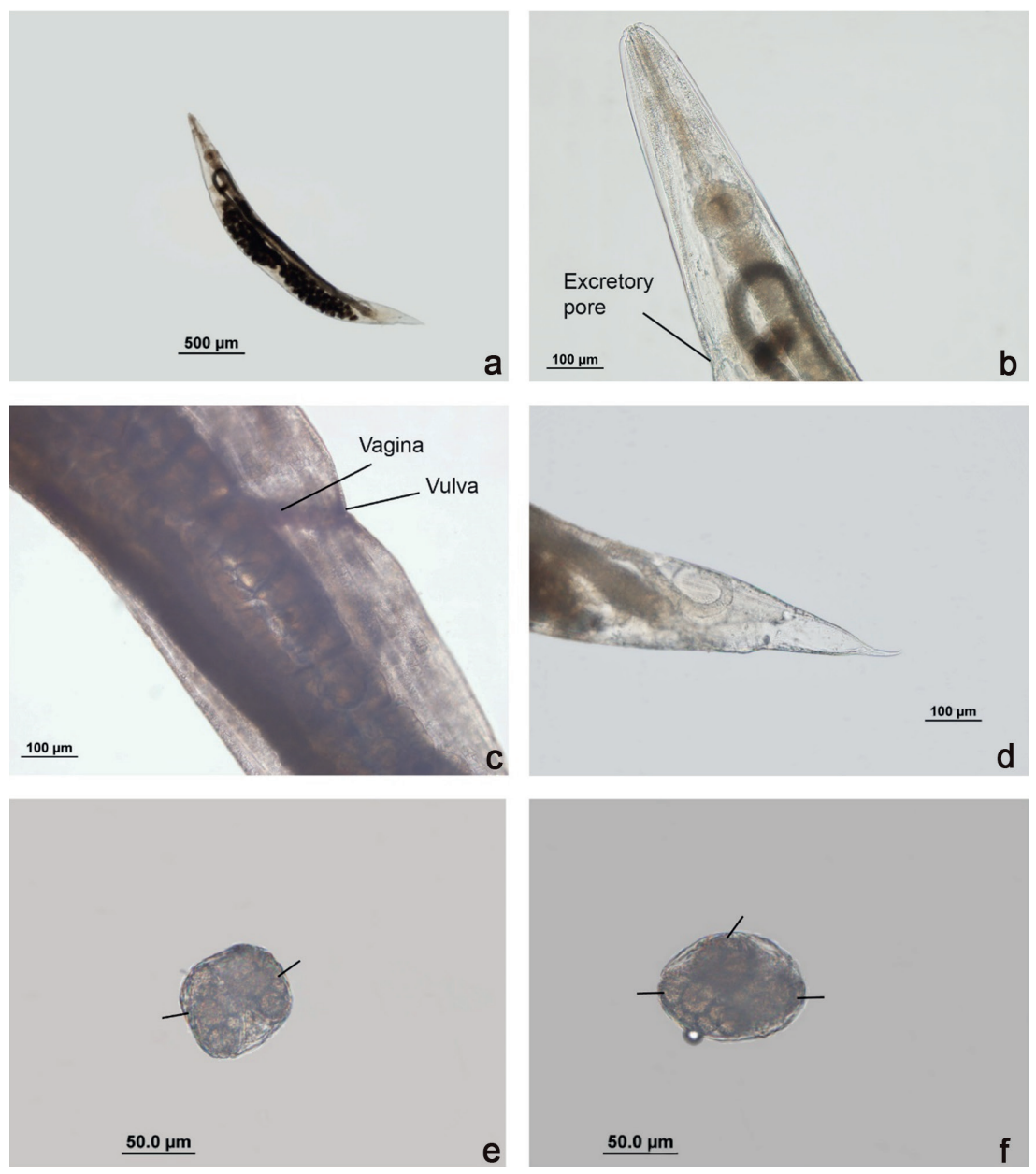

Figure 1 - Binema korsakowi. a. Female, entire. b. Cephalic region. c. Vulval region (lines showing the vulva and the vagina). d. Tail. e. Capsule containing 2 eggs (lines). f. Capsule containing 3 eggs (lines).

\section{Morphology}

level of the nerve ring: 144 (126-207), oesophagus length: 366.3 (360-387), anterior distance to the basal bulb: 272.7 (243-279), distance from anterior end to the excretory pore: 643.5 (549-738), greatest width: 391.5 (279-441), width at level of vulva: 344.2 (261-387), vulval length: 31.5 (9-45), vulval width: $9, \mathrm{~V}=53.8 \%(52 \%-60 \%)$, posterior end width: 173.7 (135-270), tail length: 327.6 (297351), egg length: 45 (36-54), egg width: 39 (36-45).

Male: $1190 \mu$ long by $90 \mu$ in maximum width of the body. Buccal cavity short. Body transversely striated throughout its whole length (Fig. 2a). 
Oesophagus $126 \mu$ long with a cylindrical corpus, a short isthmus and a basal bulb (Fig. 2b). The nerve ring is located approximately in the middle of the corpus. Excretory pore posterior to the base of the oesophagus. Nine pairs of caudal papillae, of which four pairs are pre-cloacal, one pair ad-cloacal and four pairs post-cloacal. A single median papilla between the last pair of caudal papillae at the base of the caudal spike is seen. Spicule single (Fig. 2c). Tail filiform.

\section{Morphometry}

Male $(\mathrm{n}=2)$ : total length: 1015 (840-1190), cephalic diameter: 13.5 (9-18), distance from anterior end to the nerve ring: 67.5 (63-72), width at level of the nerve ring: 54 (45-63), oesophagus length: 131 (126-136), anterior distance to the basal bulb: 99, distance from anterior end to the excretory pore: 162, greatest width: 90 , width at level of the anus: 31.5 (27-36), spicule length: 36 , spicule width: 4.5 , tail length: 54 .

\section{TAXONOMIC SUMMARY}

\section{Country: Argentina}

State: Buenos Aires

Locality: Hudson ( $34^{\circ} 47^{\prime} 25^{\prime \prime}$ S $58^{\circ} 08^{\prime} 55^{\prime \prime} \mathrm{W}$ )

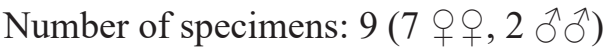

Host: Neoscapteriscus vicinus (Orthoptera: Gryllotalpidae)

Localization: hindgut

Collection number: Museo de Ciencias Naturales de La Plata (MLP-He 7309)

Binema klossae (Marchissio and Miralles

\section{DESCRIPTION}

Male: not found

\section{Morphology}

Female: fusiform body (Fig. 3a). Mouth surrounded by eight cephalic papillae and a pair of amphids.
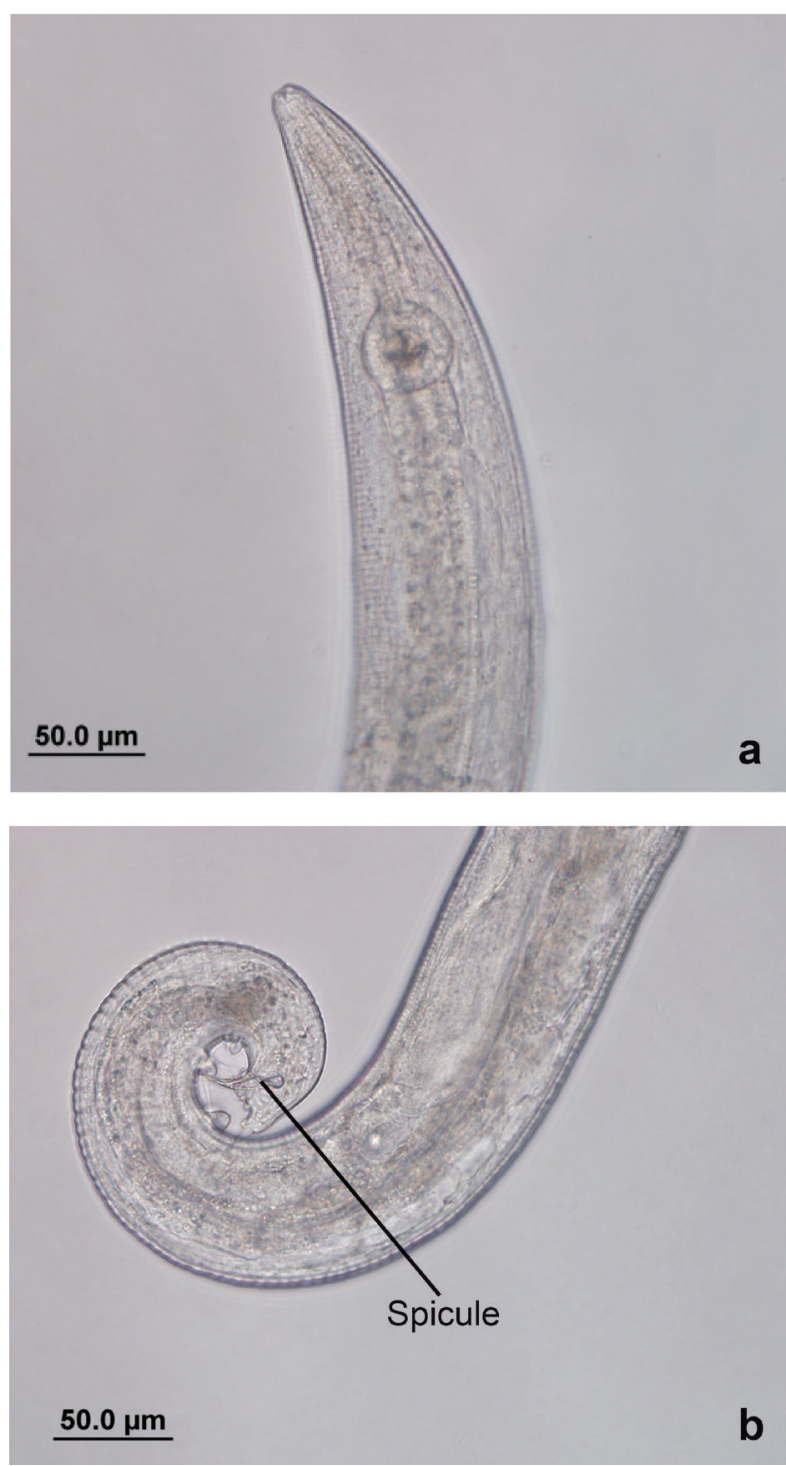

Figure 2 - Binema korsakowi. a. Male, cephalic region. b. Posterior region (line showing the spicule).

Annulated cuticle in the cephalic region, smooth in the rest of the body. Buccal ornamentation. Stoma with chitinous walls. Oesophagus with a chitinous wall-well differentiated corpus, a highly developed isthmus and a basal bulb (Fig. $3 b)$. Nerve ring situated in the middle of the corpus. Excretory pore posterior to the base of the oesophagus. Rectilinear intestine. Reproductive system didelphic amphidelphic. Vulva located at the middle of the body (Fig. 3c). Large ovoid eggs, with polar filaments surrounded or not by a 

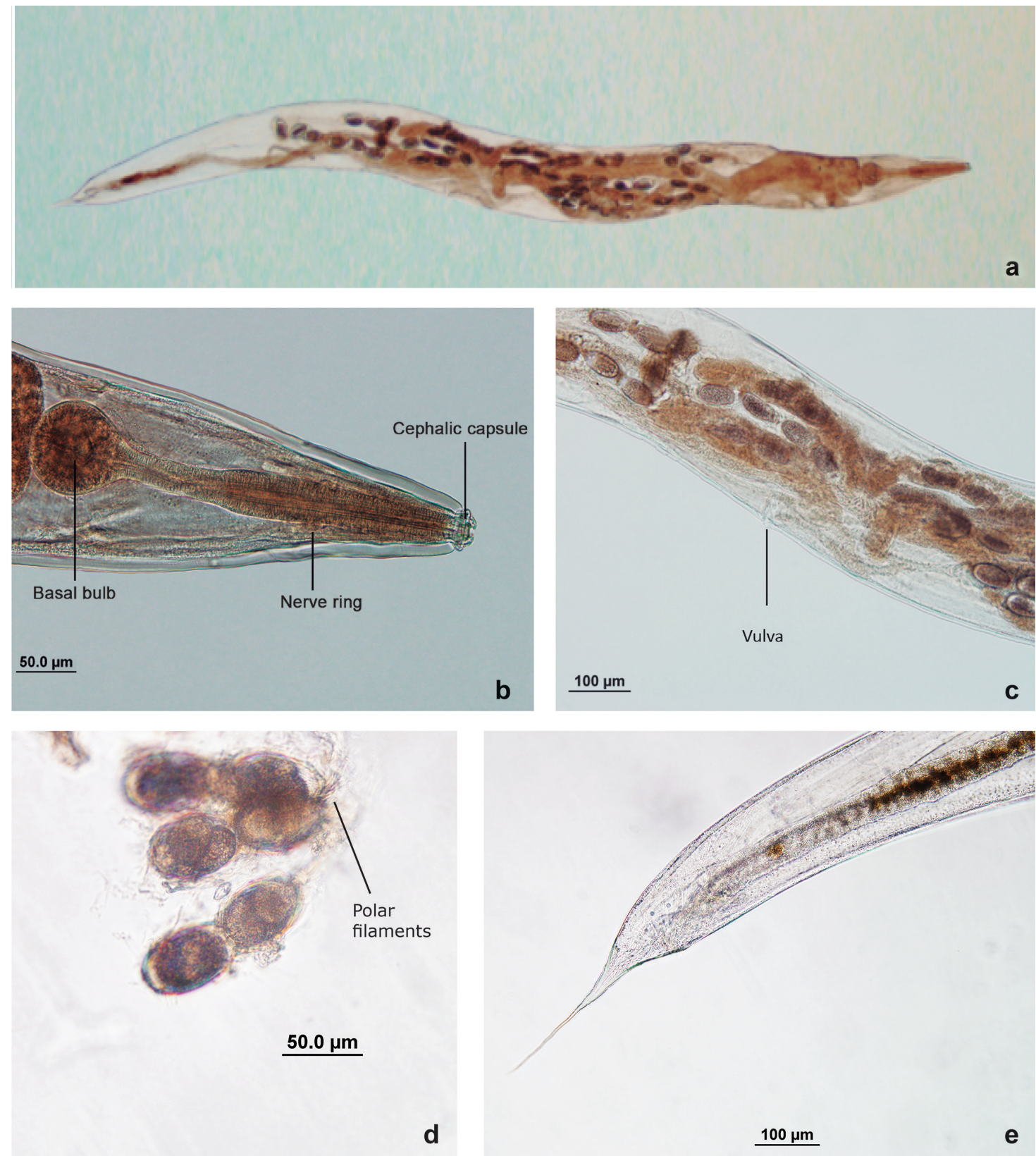

Figure 3 - Binema klossae. a. Female, entire. b. Cephalic region (lines showing the cephalic capsule, nerve ring and basal bulb). c. Vulval region (line showing the vulva). d. Eggs with polar filaments. e. Posterior region.

membranous capsule (Fig. 3d). Phasmids present. Conical tail, provided with a flagellum as a caudal appendix (Fig. 3e).

\section{Morphometry}

Female ( $n=3)$ : total length: 3952 (2640-4848), cephalic diameter: 18, distance from anterior end to the nerve ring: $117(108-126)$, width at level of the nerve ring: 93 (81-99), oesophagus length: 375 (315-405), anterior distance to basal bulb: 294 (252-315), distance from anterior end to the excretory pore: 552 (441-630), greatest width: 222 (153-261), width at level of vulva: 222 (135-270), vulval length: 36 (18-45), vulval width: 24 (18- 
$36), V=49.3 \%$ (49\% - 49.5\%), posterior end width: 93 (81-108), tail length : 297 (288-306), egg length: 58.5 (54-63), egg width: 31.5 (27-36).

\section{TAXONOMIC SUMMARY}

Country: Argentina

State: Buenos Aires

Locality: Hudson ( $34^{\circ} 47^{\prime} 25^{\prime \prime}$ S $58^{\circ} 08^{\prime} 55^{\prime}$ ' W)

Number of specimens: 3 우

Host: Neoscapteriscus vicinus (Orthoptera: Gryllotalpidae)

Localization: hindgut

Collection number: Museo de Ciencias Naturales de La Plata (MLP-He 7309)

Family Thelastomatidae

Cameronia arecoensis (Marchissio and Miralles 1987)

\section{DESCRIPTION}

\section{Morphology}

Female: fusiform body (Fig. 4a). Buccal cavity surrounded by eight cephalic papillae and a pair of amphids. Annulated cuticle evident in the cephalic region and barely perceptible in the caudal region. Short stoma. Oesophagus with a well differentiated corpus, a small isthmus and a basal bulb (Fig. 4b). Excretory pore posterior to the base of the oesophagus. Rectilinear intestine. Reproductive system didelphic amphidelphic. Vulva in the posterior third of the body (Fig. 4c). Elliptical large eggs, flattened on one of their sides and fused in pairs along their flattened faces (Fig. 4d). Conical tail (Fig. 4e).

\section{Morphometry}

Female ( $\mathrm{n}=7)$ : total length: 2516.6 (2400-2688), cephalic diameter: 18, distance from anterior end to the nerve ring: width at level of the nerve ring: oesophagus length: 363 (396-450), anterior distance to the basal bulb: 316.5 (297-369), distance from anterior end to excretory pore: 922.4 (882963), greatest width: 263.6 (252-279), width at the level of vulva: 239.1 (207-261), vulval length: 42.4 (36-45), vulval width: 24.4 (18-36), V=68.8\% (65.1\% - 76\%), posterior end width: 84.8 (63-99), tail length: 113.1 (81-136), egg length: 210 (201216), egg width: 60 (54-63).

\section{Morphology}

Male: smaller than the female. Body transversely striated throughout its whole length (Fig. 5a). Oesophagus with a cylindrical corpus, a short isthmus and a basal bulb (Fig. 5b). Excretory pore posterior to the base of the oesophagus. Testicle single, reflexed approximately in the middle of the body. Spicule single. A pair of pre-anal papillae, a pair of ad-anal papillae, and two pairs of post-anal (being the first one small), proximal to the anus and the second one more evident and situated in the base of the tail. Tail conical, slightly curved (Fig. $5 c)$.

\section{Morphometry}

Male $(\mathrm{n}=1)$ : total length: 828 , cephalic diameter: 9, distance from anterior end to the nerve ring: width at level of the nerve ring: oesophagus length: 144, anterior distance to the basal bulb: 117 , distance from anterior end to excretory pore: 171, greatest width: 72 , width at level of the anus: 36 , spicule length: 31.5 , spicule width: 4.5 , tail length: 54 .

\section{TAXONOMIC SUMMARY}

Country: Argentina

State: Buenos Aires

Locality: Hudson ( $34^{\circ} 47^{\prime} 25^{\prime}$ ' S 58 $08^{\circ}$ '55” W)

Number of specimens: $8(7$ 우, 1 đ)

Host: Neoscapteriscus vicinus (Orthoptera: Gryllotalpidae)

Localization: hindgut 

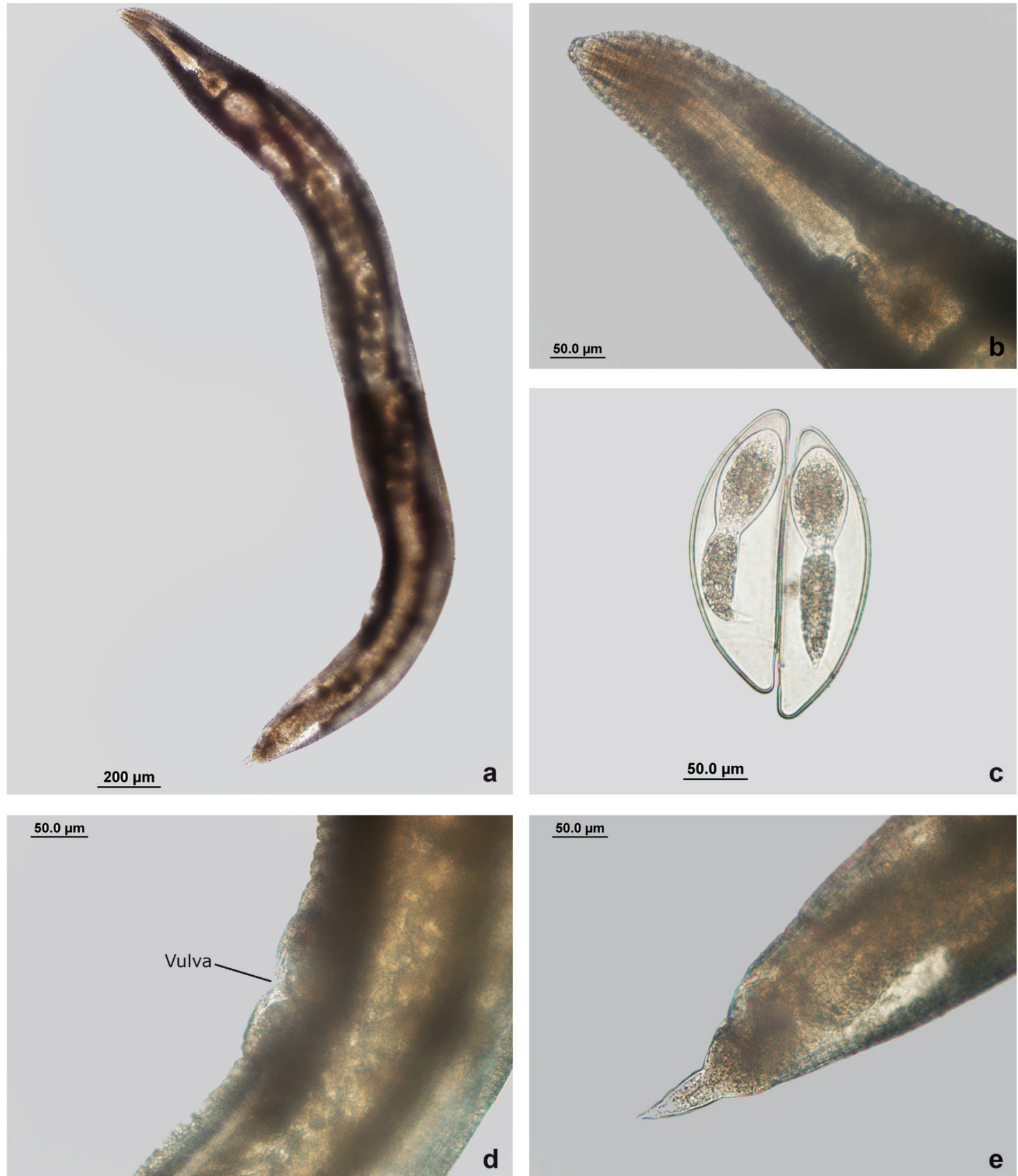

Figure 4 - Cameronia arecoensis. a. Female, entire. b. Cephalic region. c. Elliptical large eggs. d. Vulval region (line showing the vulva). e. Tail.

Collection number: Museo de Ciencias Naturales de La Plata (MLP-He 7309)

\section{MOLECULAR ANALYSIS}

\section{DNA characterization}

The 18S rRNA fragments sequenced obtained were 889 bp for B. korsakowi, 880 bp for B. klossae, and 899 for $C$. arecoensis. The BLAST tools grouped the two new sequences of Binema with the sequences JX852712, JX852711, KC763368 belonging to B. korsakowi (99\%), Binema ornata Travassos, 1925 (94\%) and Binema mirzaia (Basir 1942) Basir 1956 (86\%), respectively; and $C$. arecoensis with the sequence $\mathrm{KC} 763369$ belonging 

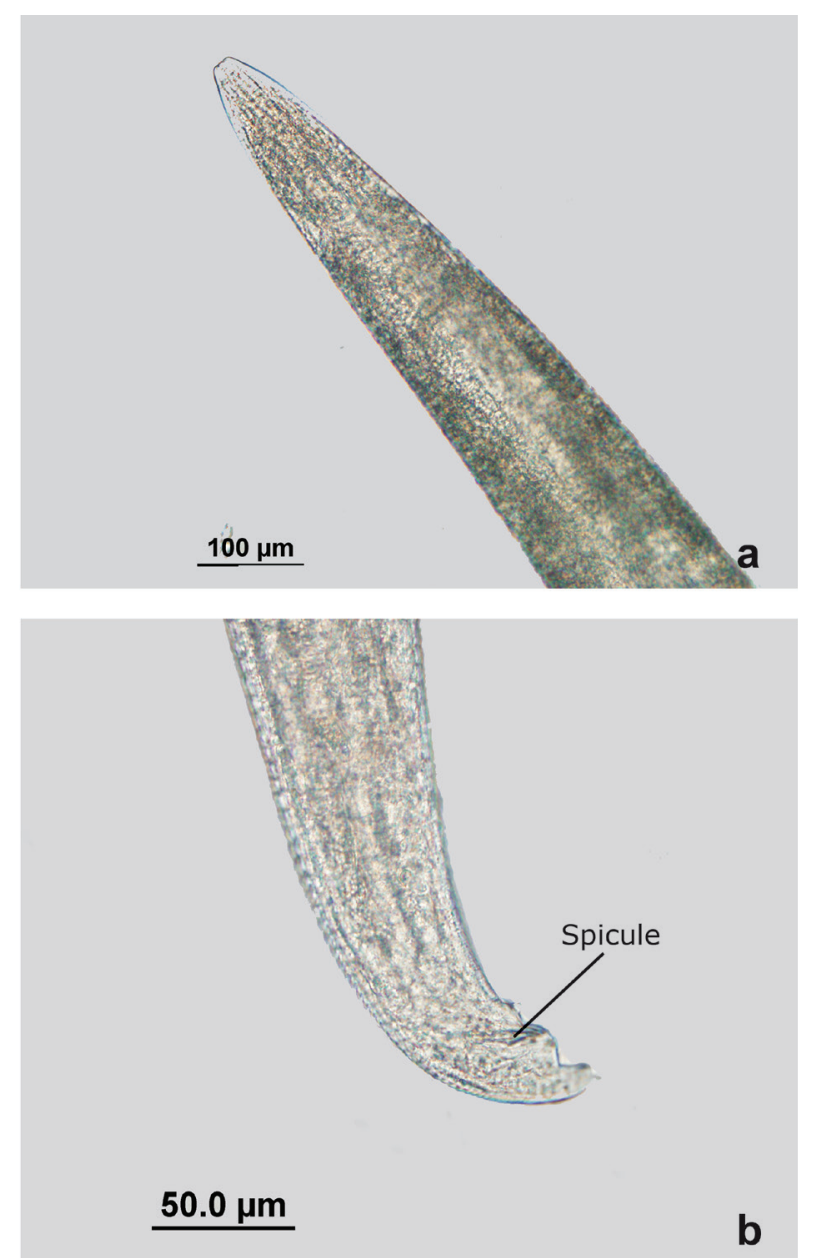

Figure 5 - Cameronia arecoensis. a. Male, cephalic region. b. Posterior region (line showing the spicule).

to Cameronia nisari Parveen and Jairajpuri, 1985 $(97 \%)$.

\section{DISCUSSION}

The family Travassosinematidae gathers mainly nematodes of mole-crickets (Binema and Pulchrocephala), whereas only one genera (Travassosinema) was found in diplopods (Adamson and van Waerebeke 1992b).

The genus Binema is characterized by having eggs broadly oval with polar filaments deposited in capsules containing 2-3 eggs or non-encapsulated and laid in pairs, conical tail or rounded with short or long caudal appendage or flagella-like, with or without fine striations near its tips and caudal extremity in male, conical, filiform or spike-like (Shah et al. 2012). Eleven species have been reported worldwide: Tewarson and Gupta (1978) described B. thapari, Parveen and Jairajpuri (1985) described B. parva, Singh and Singh (1990) did the same with $B$. chauhani and Adamson and van Waerebeke (1992b) cited 4 species in their review of the Travassosinematidae family. Singh (2003) described the species B. atrophicaudata in India, and a year later Shah and Rizvi (2004) described $B$. annulinervus.

In South-America 4 species were isolated: Binema ornata (Travassos 1925) in Brazil from Gryllotalpa africana (Beauvois 1805) and $G$. europaeus L., Binema korsakowi in Brazil and Argentina from $G$. africana, G. europaeus, $G$. vulgaris Latreille 1804 and Neocurtilla claraziana Saussure 1874, while B. bonaerensis (Camino and Reboredo 1999) and B. klossae in Argentina from N. claraziana.

Marchissio and Miralles (1993) did not provide a description morphometric values for B. korsakowi, so this kind of information for an Argentinian isolate of this species was lacking. Our investigation contributes with the first description and morphometric data for a $B$. korsakowi isolate in Argentina. We also compared the B. korsakowi population reported in the present study with that of Farooqui's (1968): In our isolate the body of the male was longer $(1190 \mu$ vs $810 \mu)$, and wider $(90 \mu$ vs $60 \mu$ ) respect to Farooqui's population, whilst the position of the nerve ring from the head end $(62 \mu$ vs $60 \mu)$, the spicule length $(4.5 \mu$ vs $4 \mu)$ and the tail length (54 $\mu$ vs $60 \mu)$ presented similar values. The prominent lateral alae which runs from the caudal appendage up to the level of the nerve ring seen in Farooqui's worm was absent in ours. Regarding the female, the body was longer ( $2800 \mu$ vs $2100 \mu)$ and wider $(441 \mu$ vs $280 \mu)$. The nerve ring position from the head end was almost identical $(162 \mu$ vs $160 \mu)$ but the excretory pore 
was located further away $(640 \mu$ vs $530 \mu)$. The oesophagus was shorter $(360 \mu$ vs $420 \mu)$ and the tail was longer $(320 \mu$ vs $280 \mu)$. The eggs were shorter $(45 \mu$ vs $59 \mu)$, but wider $(39 \mu$ vs $34 \mu)$.

Binema klossae was first described by Marchissio and Miralles in 1993. When we compare our population (females) with the one described by Marchissio and Miralles, we noticed that in our isolate the body was longer $(4848 \mu$ vs $4200 \mu)$, the width was quite similar $(261 \mu$ vs $270 \mu)$, the oesophagus ( $405 \mu$ vs $420 \mu$ ), tail ( $306 \mu$ vs $313 \mu$ ), the nerve ring position from the head end $(126 \mu \mathrm{vs}$ $165 \mu)$ and the position of the excretory pore $(630 \mu$ vs $810 \mu)$ were shorter. Eggs were almost identical in length $(63 \mu$ vs $64 \mu)$ and width ( $36 \mu$ vs $34.8 \mu)$.

Respect to the genus Cameronia; 12 species have been cited so far. In 1984, Parveen and Jairajpuri described C. klossi. Marchissio and Miralles (1987) described C. arecoensis. Adamson and van Waerebeke (1992 a) cited 6 species in their review of the Thelastomatidae family. Reboredo and Camino (2001) described C. laplatae and Rizvi and Jairajpuri (2002) described C. basiri. Finally, Shah (2007) described C. manipurensis and $C$. triovata, the latter based only in female morphology. When we compared our $C$. arecoensis populations with that of Marchissio and Miralles (1987), the female body length of our isolate (2688 $\mu$ vs $4605 \mu)$ and the body width $(279 \mu$ vs $465 \mu)$ were shorter respect to the population described by these authors, the oesophagus $(369 \mu$ vs 600 $\mu)$ and tail length were also shorter (136 $\mu$ vs 297 $\mu)$, and the excretory pore was closer to the head (963 $\mu$ vs $1050 \mu)$. The eggs were longer $(216 \mu$ vs $194 \mu)$ and wider $(64 \mu$ vs $58 \mu)$. With regard to the male, the body length was larger ( $828 \mu$ vs 803 $\mu)$, the body width smaller $(72 \mu$ vs $89 \mu)$ and the oesophagus longer $(144 \mu$ vs $139 \mu)$. The excretory pore was closer to the head end $(171 \mu$ vs $197 \mu)$. The spicule $(31.5 \mu$ vs $29 \mu)$ and the tail length were almost identical $(54 \mu$ vs $55 \mu)$.
The Blast analysis confirmed the identity of Binema korsakowi with $1 \%$ difference with the sequence of the same species deposited in the GenBank, and also the identity of B. klossae as a member of the genus Binema. Cameronia arecoensis was $97 \%$ similar to $C$. nisari, supporting genetically the position of our specimen as a species in Cameronia.

This paper contributes with a morphological redescription of these three species, the first molecular characterization of an Argentinian isolate of B. korsakowi, and the first molecular characterization of $B$. klossae and $C$. arecoensis in the world. The results supported the validity of these three nematode species based on morphological and molecular observations.

\section{AUTHOR CONTRIBUTIONS}

JMR and MFA did the samplings, JMR, MFA and MM wrote the manuscript; JMR identified and characterized morphologically the nematodes and WF and MM performed the molecular analysis.

\section{ACKNOWLEDGMENTS}

The authors would like to thank English professor Antonela Capurro for the revision of this manuscript.

\section{REFERENCES}

ADAMSON ML AND VAN WAEREBEKE D. 1992a. Revision of Thelastomatoidea, Oxyurida of invertebrate hosts I. Thelastomatidae, Protrelloididae and Pseudonymidae. Syst Parasitol 20: 21-63.

ADAMSON ML AND VAN WAEREBEKE D. $1992 \mathrm{~b}$. Revision of Thelastomatoidea, Oxyurida of invertebrate hosts II. Travassosinematidae. Syst Parasitol 21: 169-188.

ADAMSON ML AND VAN WAEREBEKE D. 1992c. Revision of Thelastomatoidea, Oxyurida of invertebrate hosts II. Hystrignathidae. Syst Parasitol 22: 111-130.

BALDI G, GUERSCHMAN JP AND PARUELO JM. 2006. Characterizing fragmentation in temperate South America grasslands. Agric Ecosyst Environ 116: 197-208. 
BASIR MA. 1956. Oxyuroid parasites of Arthropoda. A monographic study. 1 Thelastomatidae. 2 Oxyuroidae. Zool, Stuttgart 38(108): $79 \mathrm{p}$.

CAMINO NB AND ACHINELLY NB. 2008. Nematodos de insectos (generalidades). Buenos Aires, Dunken, $117 \mathrm{p}$.

CAMINO NB AND REBOREDO GR. 1999. Binema bonaerensis n. sp. (Oxurida: Thelastomatidae) Parasite of Neocurtilla claraziana Saussure (Orthoptera, Gryllotalpidae) in Argentina. Mem Inst Oswaldo Cruz 94(3): 311-313.

FAROOQUI MN. 1968. On a new species of Cameronia Basir, 1948 from Gryllotalpa africana. Riv Parasitol 29: 269272.

KEARSE M ET AL. 2012. Geneious Basic: an integrated and extendable desktop software platform for the organization and analysis of sequence data. Bioinformatics 28(12): 1647-1649.

MARCHISSIO SL AND MIRALLES DAB. 1987. Cameronia arecoensis sp. nov. Parásito intestinal de Neocurtilla claraziana (Saussure, 1974) (Orthoptera: Gryllotalpidae). Neotrópica 33(90): 127-132.

MARCHISSIO SL AND MIRALLES DAB. 1993. Talpicola klossae sp. n. y nuevo registro de Binema korsakowi (Sergiev, 1923) (Nematoda: Thelastomatidae) parásitos de Neocurtilla claraziana (Orthoptera: Gryllotalpidae). Neotrópica 39(101-102): 79-82.

PARVEEN R AND JAIRAJPURI DS. 1984. Cameronia klossi sp. n. (Nematoda: Thelastomatidae) from the mole cricket, Gryllotalpa Africana from Aligarh. Rev Iber Parasitol 44(2): 153-158.

PARVEEN R AND JAIRAJPURI DS. 1985. Binema parva sp. n., a parasitic nematode of the mole cricket Gryllotalpa africana. Rev Parassitol 46: 347-350.

POINAR GO JR. 1975. Entomogenous nematodes: a manual and host list of insect-nematode associations. Leiden, Brill, Netherlands.
REBOREDO GR AND CAMINO NB. 2001. Una nueva especie del género Cameronia Basir (Oxyurida: Thelastomatidae) parásita de Gryllodes laplatae Sauss (Orthoptera:Gryllidae) en Argentina. Bol Chil Parasitol 56: $42-44$.

RIZVI AN AND JAIRAJPURI DS. 2002. Studies on a new and some known species of insect oxyurid nematodes. Rev Iber Parasitol 62: 1-7.

SHAH MM. 2007. Two new species of Cameronia Basir, 1948 (Oxyurida, Thelastomatoidea, Thelastomatidae) from Manipur, North-East India. Acta Parasitol 52(3): 225-232.

SHAH MM, MOHILAL N AND PRAMODINI BINA L. 2012. Parasitic Nematodes of some Insects from Manipur, India. Ed. Dr. Mohammad Manjur Shah, 206 p.

SHAH MM AND RIZVI AN. 2004. Some studies on three known species of the genus Binema Travassos, 1925 (Travassosinematidae: Thelastomatidae) from Manipur, North-East India. Parasitologia 46: 317-326.

SINGH HS AND MALTI. 2003. On a known and some unknown species of nematode parasites of Gryllotalpa africana. J Exp Zool 6(2): 329-350.

SINGH HS AND SINGH PK. 1990. A new species of the genus Mirzaiella (Basir). Indian J Parasitol 14: 201-202.

SINGH N, CHAUDHARY A AND SINGH HS. 2013. Morphological redescription and molecular characterization of three species of Travassosinematidae (Nematoda: Oxyurida: Thelastomatoidea) from Gryllotalpa africana Beauv (Orthoptera: Gryllotalpidae). Bioinformation 9(16): 818-823.

TEWARSON NC AND GUPTA V. 1978. Nematode parasites of invertebrates. Indian J Zoot 17: 21-24.

TRAVASSOS L. 1925. Quelques nematodes du Gryllotalpa. Paris, C R Soc Biol 93: 140-147. 